\title{
LIETUVOS IMUNOPROFILAKTIKOS PROGRAMA - SKIEPIJIMO APIMČIŲ REZULTATYVUMO VERTINIMAS
}

\author{
Irma Čaplinskienè \\ Mykolo Romerio universiteto Politikos mokslų institutas \\ Valakupių g. 5, Lt-10101 Vilnius, Lietuva \\ Elektronis paštas caplinskiene.irma@gmail.com \\ Telefonas (+370 5) 2740611 \\ Pateikta $2014 \mathrm{~m}$. sausio $31 \mathrm{~d}$, parengta spausdinti $2014 \mathrm{~m}$. vasario $26 \mathrm{~d}$. \\ doi:10.13165/SPV-14-1-6-09
}

\section{Santrauka}

Straipsnio tikslas - jvertinti Lietuvos Nacionalines imunoprofilaktikos programos 2009-2013 m. igyvendinima, nustatant tarpini pasiekta tiksla pagal rezultatyvumo kriteriju.

Straipsnyje nagrinejamos skiepijimu apimčiu tendencijos pagal ligas, nuo kuriu skiepijama pagal Lietuvos vaiku profilaktiniu skiepijimy kalendorių. Šiame kalendoriuje numatyti skiepai yra kompensuojami iš Privalomojo sveikatos draudimo fondo biudžeto, igyvendinant Nacionaline imunoprofilaktikos programa. Rezultatyvumas nustatytas lyginant planuotus tikslo pasiekimo rodiklius su faktiniais. Nustatyta, kad 2012 metais skiepijimu apimtys nuo visu infekciju sieke daugiau nei 90 proc., ir tai reiškia, kad Nacionalinés imunoprofilaktikos programos tikslas - „išlaikyti ne mažesnį kaip 90 proc. vaiku skiepijimo masta visoje šalyje“ pagal rezultatyvumo kriteriju pasiektas. Tačiau taip pat konstatuota, kad pastaraisiais metais nustatomos mažejančios skiepijimu apimčiu tendencijos ir Lietuvos sveikatos programoje užsibrěžtas tikslas iki 2010 metu - didinti imunizavimo mastus nuo užkrečiamujų ligu pagal Lietuvos skiepu kalendoriu iki 97-98 proc., praktiškai liko neigyvendintas. Tam ịtakos galejo turèti šalyje plintantys antivakcininiai judejimai, per visuomenés informavimo priemones skleidžiama mokslu nepagrįsta informacija apie skiepus.

Reikšminiai žodžiai: skiepijimų apimtys, vakcinacijos mastai, rezultatyvumas.

\section{Ivadas}

Pasaulio sveikatos organizacijos (PSO) dokumente „Pasaulinė imunizacijos strategija ir vizija“ reglamentuojama pasaulinè imunizacijos politika, kurioje rekomenduojama, kad valstybės turi pasiekti ir išlaikyti šalies skiepijimo apimtis ne mažesnes nei 90 proc. ir ne mažesnes nei 80 proc. kiekvienoje administracineje teritorijoje ${ }^{1}$.

1 World Health Organization. Global Immunization Vision and Strategy 2006-2015. Geneva, 2005 (WHO/IVB/05.05). 
Imunoprofilaktika - tai viena iš svarbiausių kovos su užkrečiamosiomis ligomis formų, kurios siektini tikslai Lietuvos sveikatos programoje (LSP) ${ }^{2}$ išdèstyti specialiųjų tikslų dalyje. Siekiant LSP numatytų imunoprofilaktikos tikslų, Lietuvoje igyvendinama Nacionalinė imunoprofilaktikos programa bei kitos priemonès. Lietuvos sveikatos programos imunoprofilaktikos dalyje (3.3.5.4. poskyryje) buvo iškelti trys tikslai iki 2010 metų, tarp kurių „didinti imunizavimo mastus prieš užkrečiamąsias ligas pagal Lietuvos skiepų kalendorių (iki 97-98proc.). LSP igyvendinimo laikotarpiu atliekant LSP vertinimus imunoprofilaktikos tikslų pasiekimo vertinimui skirtas nepakankamas dėmesys ${ }^{3} .2008$ metais atliekant tarpinị LSP vertinimą ${ }^{4}$ apsiribota trumpu imunoprofilaktikos situacijos aprašymu bei konstatuota, kad skiepijant pagal Lietuvos Respublikos vaikų profilaktinių skiepijimų kalendorių pasiektos pakankamai aukštos skiepijimų apimtys (94-99 proc. paskiepytų ịvairiose amžiaus grupėse), leidžiančios suvaldyti užkrečiamąsias ligas, nuo kurių skiepijama. Iki 2010 metų LSP numatytų tikslų igyvendinimo vertinimas pateiktas dviejuose dokumentuose: 2011 metu Nacionalinès sveikatos tarybos (toliau - NST) metiniame pranešime ${ }^{5}$ ir ekspertiniame vertinime „Sveikatos sistemos reformų analizé“6. NST metiniame pranešime apie imunoprofilaktiką iš viso nèra užsiminta, o ataskaitoje „Sveikatos sistemos reformų analizė“ imunoprofilaktikos dalyje vakcinacijos mastas (aprèptis) taip pat nevertinta.

PSO duomenų bazèje vertinant 2005-2010 metų Lietuvos imunizacijos rodiklius ir valdymo kokybę, pateikti tokie vertinimai: Lietuvoje yra daugiametis imunoprofilaktikos planas; parengti metiniai darbo planai; ị igyvendinimą ịtrauktos visos administracinès teritorijos; analizuojami jų duomenys; organizuojami susitikimai su aukštesnio lygio vadovais; remiamas mokymas ir informuojami visi rajonai; veikia patariamoji grupe nacionalinès imunoprofilaktikos klausimais ${ }^{7}$.

2009-2013 metais Lietuvoje igyvendinta Nacionalinè imunoprofilaktikos programa (NIP), kuri patvirtinta sveikatos apsaugos ministro įsakymu ${ }^{8}$. Rengiant šią programą atsižvelgta ị ankstesnès (2006-2008) programos ${ }^{9}$ rezultatus, PSO rekomendacijas, ES teisès aktų, reglamentuojančių vakcinomis valdomų užkrečiamųjų ligų epidemiologinę priežiūrą ir profilaktiką, nuostatas bei kitus dokumentus. Pagrindinè imunoprofilaktikos programos nuostata - paskiepyti kuo daugiau vaikų ir kaip galima anksčiau, t. y. sukurti aukšto lygio kolektyvinị vaikų imunitetą, nes kiekvienais metais likusi nepaskiepytų vaikų dalis po tam tikro

2 Lietuvos Respublikos Seimo 1998 m. liepos 2 d. nutarimas Nr. VIII-833 „Dèl Lietuvos sveikatos programos patvirtinimo". Valstybès žinios. 1998, Nr. 64-1842.

3 Dildyte, M. Lietuvos sveikatos programos igyvendinimas - imunoprofilaktikos pokyčiu vertinimas. Magistro baigiamasis darbas. Vilnius: Mykolo Romerio universitetas, 2012.

4 Lietuvos Respublikos sveikatos apsaugos ministro $2008 \mathrm{~m}$. gruodžio $4 \mathrm{~d}$. ịsakymas Nr. V-1183 „Dèl Lietuvos sveikatos programos igyvendinimo tarpinio vertinimo ataskaitos patvirtinimo" [interaktyvus]. [žiūreta 2014- 01-03]. <www.sam.lt>.

5 Nacionalinès sveikatos tarybos metinis pranešimas. Lietuvos sveikatos programa: rezultatai ir išvados, 2011.

6 Sveikatos sistemos reformų analizè. Ataskaita [interaktyvus]. [žiūrèta 2014- 01-03]. <http://www.sveikatosprojektai.org/node/40>.

7 World Health Organization. Immunization Profile - Lithuania [interaktyvus]. [žiūrèta 2014- 01-03]. $<$ www.who.int/imunization>.

8 Lietuvos Respublikos sveikatos apsaugos ministro2009 m. kovo 31 d. ịsakymas Nr. V-242 „Dèl Nacionalinès imunoprofilaktikos 2009-2013 metų programos patvirtinimo“. Valstybès žinios. 2009, Nr. 40-1534.

9 Lietuvos Respublikos sveikatos apsaugos ministro 2006 m. rugpjūčio 8 d. ịsakymas Nr. V-682 „Dèl Nacionalinès imunoprofilaktikos 2006-2008 metų programos patvirtinimo“. Valstybés žinios. 2006, Nr. 88-3486. 
laikotarpio gali lemti epideminị infekcinių susirgimų pakilimą. Vaikų imunizacija atliekama vadovaujantis Lietuvos Respublikos vaikų profilaktinių skiepijimų kalendoriumi ${ }^{10}$.

2009-2013 metų vienas iš Nacionalinès imunoprofilaktikos programos tikslų - pasiekti ir išlaikyti pakankamą vaikų skiepijimų mastą (ne mažiau kaip 90 proc. šalyje ir kiekvienoje administracinejje teritorijoje) bei rezultatas - išlaikyti ne mažesnị kaip 90 proc. vaikų skiepijimo mastą visoje šalyje ir kiekvienoje administracineje teritorijoje.

Viešiosios politikos programų vertinimas yra sistemingas ir objektyvus planuojamų vykdyti, vykdomų ar baigtų vykdyti programų vertinimas vienu ar keliais šiais pagrindiniais programų vertinimo aspektais ${ }^{11}$ :

1. tinkamumo - vertinama, kaip programos tikslai ir uždaviniai atitinka visuomenès poreikius;

2. efektyvumo - vertinama, ar rezultatai pasiekti su mažiausiomis sąnaudomis (nustatomas rezultatų ir jiems pasiekti būtinų ar panaudotų sąnaudų (išteklių) santykis);

3. rezultatyvumo - vertinamas programos tikslų ir uždavinių pasiekimo laipsnis (jų pasiekimo tikimybè), lyginant planuotus rodiklius su faktiniais;

4. naudingumo - vertinama, ar planuoti (ir gauti) programos rezultatai atitinka tiesioginių ir netiesioginių naudos gavejų poreikius;

5. tęstinumo - vertinama, ar programos rezultatai ir poveikis yra ilgalaikiai.

Rezultatyvumas - programos vertinimo kriterijus, pagal kurị vertinamas numatytų ir igyvendintų programos ar jos dalies tikslų bei uždavinių santykis, t. y. jų pasiekimo laipsnis. Programos rezultatyvumas gali būti matuojamas ne tik pasibaigus programos igyvendinimui, bet ir programos igyvendinimo metu (rezultatyvumo tikimybė). Pagal rezultatyvumo kriterijų dažniausiai vertinami programos produktai ir rezultatai, bet ne poveikis. Aukštesnio lygio tikslų pasiekimo laipsnis arba jo tikimybė matuojama poveikio kriterijumi ${ }^{12}$.

Straipsnio tikslas - ịvertinti Lietuvos Nacionalinès imunoprofilaktikos programos 2009-2013 metams ịgyvendinimą, nustatant tarpinị pasiektą tikslą pagal rezultatyvumo kriterijų. Vertintas siektino tikslo „išlaikyti ne mažesnị kaip 90 proc. vaikų skiepijimo mastą visoje šalyje“ rezultatas.

\section{Metodologija ir medžiaga}

Vertinant 2009-2013 metų Nacionalinès imunoprofilaktikos programos tikslo pasiekimo lygi (rezultatyvumą) vadovautasi viešosios politikos programų vertinimą apimančiu Lietuvos Respublikos Vyriausybès nutarimu „Dèl strateginio planavimo metodikos patvirtinimo "13. Šiame nutarime nurodomi penki pagrindiniai viešosios politikos programų vertinimo kriterijai: tinkamumas, efektyvumas, rezultatyvumas, naudingumas, tęstinumas. Šiame straipsnyje vertinimas atliktas pagal vieną kriterijų - rezultatyvumą. Rezultatyvumo rodiklis nustatytas ịvertinant skiepijimo apimčių mastą, taikant lyginamosios statistikos metodą: lygintas rezultato pasiekimo laipsnis su planuotu faktiniu 2012 metų rodikliu. Tai tarpinis vertinimas, nes oficialių duomenų apie nacionalines skiepijimų apimtis 2013 metais

10 Lietuvos Respublikos sveikatos apsaugos ministro 2007 m. gruodžio 22 d. ịsakymas Nr. V-1066 „Dèl Lietuvos Respublikos vaikų profilaktinių skiepijimų kalendoriaus patvirtinimo“. Valstybés žinios. 2008, Nr. 1-27.

11 Lietuvos Respublikos Vyriausybès 2002 m. birželio 6 d. nutarimas Nr. 827 „Dèl strateginio planavimo metodikos patvirtinimo“. Valstybès žinios. 2002, Nr. 57-2312; 2010, Nr. 102-5279.

12 Lietuvos Respublikos finansų ministerija. ES struktūrinès paramos vertinimas: metodinès gairès. Vilnius, 2010.

13 Lietuvos Respublikos Vyriausybès 2002 m. birželio 6 d. nutarimas Nr. 827, supra note 11. 
(programos pabaigoje) dar nèra. Vertinami oficialūs, viešai prieinami statistiniai duomenys apie skiepijimų apimtis Lietuvoje bei sergamumą skiepais valdomomis infekcijomis ${ }^{14}$.

\section{Rezultatai ir jų aptarimas}

Vaikų imunizacija atliekama vadovaujantis Lietuvos Respublikos vaikų profilaktinių skiepijimų kalendoriumi, pagal kuri naujagimiai ir vaikai skiepijami nuo tuberkuliozès (BCG vakcina), hepatito $B$, difterijos, stabligès, kokliušo, poliomielito, tymų, epideminio parotito, raudonukès, B tipo Haemophilus influenzae infekcijos. Skiepijimo kalendorius - tai svarbiausias skiepijimų planavimo dokumentas, kuriame nurodyta tam tikra skiepų tvarka (eiliškumas, laiko intervalai tarp skiepų), atsižvelgiant ị vaiko amžių. Tokia tvarka sudaryta tam, kad organizme laiku susiformuotų imunitetas infekcijoms ${ }^{15}$.

Lietuvoje imunoprofilaktika teikiama tik gavus asmenų sutikimą, išskyrus ịstatymo nustatytus atvejus, kai kyla reali grèsmė gyventojams susirgti pavojingomis užkrečiamomis ligomis, o kitos priemonès negarantuoja šių ligų plitimo ribojimo ${ }^{16}$. Skiepijimų apimtys Lietuvoje pagal skiepijimų kalendorių pateiktos 1 lentelèje.

1 lentelè. Skiepijimo apimtys Lietuvoje 2005-2012 m. procentais

\begin{tabular}{|l|r|r|r|r|r|r|r|r|}
\hline \multicolumn{1}{|c|}{ Metai } & $\mathbf{2 0 0 5}$ & $\mathbf{2 0 0 6}$ & $\mathbf{2 0 0 7}$ & $\mathbf{2 0 0 8}$ & $\mathbf{2 0 0 9}$ & $\mathbf{2 0 1 0}$ & $\mathbf{2 0 1 1}$ & $\mathbf{2 0 1 2}$ \\
\hline Vakcina & & & & & & & & \\
\hline BCG (naujagimiai) & 99,4 & 99,4 & 99,3 & 99,3 & 99,5 & 98,9 & 97,8 & 97,9 \\
\hline Hepatitas B (naujagimiai) & 99 & 99,4 & 99 & 99,1 & 99 & 98,3 & 95,7 & 93,2 \\
\hline Difterija/stabligé (1 metai) & 94 & 94 & 94,9 & 95,8 & 97,4 & 94,8 & 94,8 & 92,8 \\
\hline Kokliušas (1 metai) & 94 & 94 & 94,9 & 95,8 & 97,4 & 94,8 & 94,8 & 92,8 \\
\hline Poliomielitas (1 metai) & 97,3 & 97,3 & 97,8 & 95,8 & 97,4 & 94,8 & 94,8 & 92,8 \\
\hline Tymai (2 metai) & 97,2 & 96,6 & 96,9 & 97 & 97 & 96,1 & 93,7 & 93,4 \\
\hline Parotitas (2 metai) & 97,2 & 96,6 & 96,9 & 97 & 97 & 96,1 & 93,7 & 93,4 \\
\hline Raudonuke (2 metai) & 97,2 & 96,6 & 96,9 & 97 & 97 & 96,1 & 93,7 & 93,4 \\
\hline
\end{tabular}

Užkrečiamųjų ligų ir AIDS centro duomenys, 2013

2012 metais (1 lentelè) skiepijimų apimtys nuo visų infekcijų siekè daugiau nei 90 proc. ir tai reiškia, kad Nacionalinès imunoprofilaktikos programos tikslas - „išlaikyti ne mažesnị kaip 90 proc. vaikų skiepijimo mastą visoje šalyje“ pagal rezultatyvumo kriterijų pasiektas. Toks vaikų profilaktinių skiepijimų mastas atitinka PSO dokumente suformuluotus tikslus valstybès turi pasiekti ir išlaikyti skiepijimo apimtis mažiausiai 90 procentų. Tačiau vertinant 2009-2012 metų skiepijimų tendencijas, aiškiai stebima skiepijimo apimčių mažejimo tendencija Lietuvoje, kas kelia nerimą, kad skiepijimų apimtys gali sumažèti iki kritinès ribos ir dèl to ịvykti vakcinomis valdomų ligų susirgimų protrūkiai ${ }^{17}$. Kaip rodo Užkrečiamųjų ligų ir AIDS centro duomenys (2 lentelè), pavyzdžiui, susirgimų kokliušu skaičius 2012 me-

14 Užkrečiamụjų ligų ir AIDS centras. Ataskaitos. 2012 [interaktyvus]. [žiūrèta 2014- 01-03]. <www.ulac.lt>.

15 Dildyte, M. Lietuvos sveikatos programos igyvendinimas - imunoprofilaktikos pokyčių vertinimas. Magistro baigiamasis darbas. Vilnius: Mykolo Romerio universitetas, 2012.

16 Lietuvos Respublikos žmonių užkrečiamụjų ligų profilaktikos ir kontrolès ịstatymas 1996 m. rugsẻjo 25 d. Nr. I-1553. Valstybès žinios. 1996, Nr. 104-2363. 11 str.

17 Dvilevič, A. Igyvendinamos Lietuvos nacionalines imunoprofilaktikos programos 2009-2013 m. vertinimas. Magistro baigiamasis darbas. Vilnius: Mykolo Romerio universitetas, 2013. 
tais, palyginti su 2008 metais, išaugo beveik tris kartus. Kitų užkrečiamųjų ligų susirgimų atvejų skaičius išliko stabilus (difterija, stabligè, poliomielitas, tymai, raudonukè) ar nežymiai sumažejo (epideminis parotitas, virusinis hepatitas B).

2 lentelè. Susirgimų vakcinomis valdomomis infekcijomis atvejai (absol. sk.) Lietuvoje 2005-2012

\begin{tabular}{|c|c|c|c|c|c|c|c|c|}
\hline Užkrečiamoji liga & 2005 & 2006 & 2007 & 2008 & 2009 & 2010 & 2011 & 2012 \\
\hline Difterija & 0 & 0 & 0 & 2 & 0 & 0 & 1 & 0 \\
\hline Kokliušas & 64 & 6 & 18 & 51 & 233 & 19 & 30 & 154 \\
\hline Stabligė & 4 & 3 & 1 & 1 & 0 & 2 & 2 & 2 \\
\hline Poliomielitas & 0 & 0 & 0 & 0 & 0 & 0 & 0 & 0 \\
\hline Tymai & 1 & 1 & 0 & 1 & 0 & 2 & 7 & 2 \\
\hline Epideminis parotitas & 101 & 74 & 81 & 82 & 74 & 87 & 64 & 62 \\
\hline Raudonukè & 118 & 110 & 13 & 0 & 0 & 2 & 0 & 0 \\
\hline Hepatitas B (VHB) & 141 & 107 & 83 & 90 & 58 & 71 & 60 & 23 \\
\hline $\begin{array}{l}\text { Haemophilus influenzae B tipo } \\
\text { infekcija (invazinès formos) }\end{array}$ & 22 & 11 & 27 & $3 \mid$ & 1 & 2 & 3 & 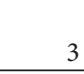 \\
\hline
\end{tabular}

Užkrečiamųjų ligų ir AIDS centro duomenys, 2013

Lyginant 2012 metų skiepijimų apimtis Baltijos šalyse, pavyzdžiui, Estijoje ir Latvijoje vakcinacijos apimtys BCG vakcina yra mažesnès (po 97 proc.) nei Lietuvoje (beveik 98 proc.). Virusinio hepatito B - mažiausios Latvijoje (91 proc.), o didžiausios Estijoje (94 proc.); Lietuvoje - 93,2 proc. Poliomielito skiepų apimtys panašiai kaip VHB, t. y. didžiausios Estijoje (94 proc.), mažiausios - Latvijoje (92 proc.), Lietuvoje beveik 93 procentai ${ }^{18}$.

Analizuojant dešimties metų (2003-2012) skiepijimų apimčių tendencijas, didejjimo tendencija yra stebima tik skiepijant difterijos, stabligès, kokliušo infekcijos vakcina 1 metų vaikus, o vakcinacijos apimtys visomis kitomis vakcinomis pastaraisiais metais ženkliai mažèja. 2003-2012 metų laikotarpiu vidutiniškai vakcinacijos apimtys BCG, VHB, poliomielito, tymų / raudonukès / epideminio parotito atitinkamai per metus mažèjo 0,14 proc., 0,48 proc., 0,38 procento $^{19}$. Sèkmingam skiepijimo programų ịgyvendinimui turi ịtakos ịvairūs veiksniai: biologiniai, epidemiologiniai, ekonominiai ir socialiniai ${ }^{20}$. Atlikus tyrimą Lietuvoje, dèl ko pastaraisiais metais mažėjo vakcinacijos apimtys, nustatytos galimos priežastys, kurios susistemintos ị šias išvadas: 1) ịtakos turèjo žiniasklaida, nes daug negatyvios informacijos apie skiepus buvo skleidžiama iš ịvairų žiniasklaidos priemonių, o visuomenè neigiamą nuomonę susidaro dèl antivakcininès propagandos žiniasklaidoje, 2) nepakankama medikų kvalifikacija / veiklumas, 3) visuomenès patikimo informuotumo trūkumas, 4) mažas sveikatos politikų dèmesys, 5) gydytojų darbo organizavimo problemos ${ }^{21}$. Europoje atliktų tyrimų duomenimis, pagrindinès tèvų atsisakymo skiepyti savo vaikus priežastys yra žinių trūku-

18 Country summaries of WHO/UNICEF estimated and official immunization coverage [interaktyvus]. [žiūrèta 2014- 01-03]. <http://apps.who.int/immunization_monitoring/globalsummary/wucoveragecountrylist.html>.

19 Užkrečiamųjų ligų ir AIDS centras. Sergamumo užkrečiamomis ligomis Lietuvoje 2012 m. apžvalga. Vilnius, 2013.

20 Glatman-Freedman, A.; Nichols, K. The effects of social determinants of imunization programs. Hum Vaccin Immunotech. 2010, (28): 5731-5737.

21 Dildytè, M., supra note 15. 
mas, šalutinių reakcijų baimè, abejonès dèl skiepų saugumo. Taip pat nustatytas ryšys su žiniasklaidos ịtaka, išsilavinimu, medikų aktyvumu skatinant skiepijimą ${ }^{22}$. Nepageidaujamų reakcijų 2012 metais Lietuvoje iš viso registruota 31 ( 2011 m. - 50). Daugiausiai nepageidaujamų reakcijų buvo stebèta po BCG vakcinos įskiepijimo. Žinant, kad kasmet vakcinuojama tūkstančiai asmenų, nepageidaujamų reakcijų skaičius yra mažas ir nẻ viena reakcija nesukèlè rimtesnių sveikatos sutrikimų ar negrịžtamų pakenkimų ${ }^{23}$.

Globalus vakcinomis valdomų ligų sergamumo sumažèjimas sukèlè ir paradoksalių rezultatų: plačioji visuomenè, o neretai ir medikai užmiršo buvusių ligų paplitimo mastą ir sunkumą, vakcinų vaidmenị ligų kontrolei, neadekvačiai sureikšmindami nepageidaujamus vakcinų poveikius. Sakoma, kad „vakcinos tapo savo sẻkmès įkaitėmis“. Neretai net medikai „tiki“ arba „netiki“ vakcinų veiksmingumu. Nuomonei apie imunizaciją formuoti didelę itaką turi visuomenès informavimo priemonès. Informaciją apie skiepus ir skiepijimąsi gyventojai gali gauti iš ịvairių šaltinių: sveikatos priežiūros specialistų, spaudos, televizijos, interneto ir kt. Dažnai visuomenès informavimo priemonès informaciją apie imunizaciją gauna iš ịvairių neoficialių šaltinių, ji dažnai būna mokslu nepagrịsta, klaidinanti. Visuomenè, neturèdama objektyvios, moksliškai pagrịstos informacijos, yra labai imli nepagrịstoms publikacijoms apie skiepų žalą, kurią dažnai skelbia įvairūs judejjimai, nukreipti prieš skiepijimą. Todèl svarbus uždavinys visuomenès ir asmens sveikatos priežiūros institucijoms - skirti pakankamai dėmesio visuomenès informavimui imunizacijos klausimais ${ }^{24}$. Akivaizdu, kad plintant antivakcininiams judejjimams Lietuvoje, Lietuvos sveikatos programoje užsibrèžtas tikslas iki 2010 metų - didinti imunizavimo mastus nuo užkrečiamųjų ligų pagal Lietuvos skiepų kalendorių iki 97-98 proc., praktiškai liko neigyvendintas. 2010 metais didesnès nei 97-98 proc. skiepijimų apimtys užregistruotos tik BCG ir VHB vakcina. Kitomis vakcinomis tokių didelių skiepijimų apimčių nepasiekta. Toks LSP užsibrěžtas tikslas vertintinas kaip per ambicingas ir sunkiai pasiekiamas dèl neįvertintų išorinių priežasčių. Lyginant skiepijimo apimčių pasiskirstymą Lietuvos administracinèse teritorijose, 2011 metais pasiskirstymas yra beveik tolygus ir sudaro daugiau nei 90 procentų ${ }^{25}$.

Vertinant programų rezultatyvumą svarbu apsibrěžti, kokie rezultatai bus vertinami. Tačiau vertinant tik vieną planuotą pasiekti rodiklị, gali būti neịvertinti kiti - tiesioginiai ir netiesioginiai programos igyvendinimo rezultatai. Be to, atliekant vertinimą, reikia atkreipti dèmesi i tai, jog rezultatai ir poveikis priklauso ir nuo išorès veiksnių. Todèl detalesnès analizès metu aktualu atsižvelgti ị ịvairius išorès veiksnius. Rezultatyvumo metodas pritaikomas tik tam tikroje srityje, t. y. tinka atsakyti tik ị tam tikrus klausimus, ne visada ir ne visais atvejais apie programos sẻkmingumą sužinoma surinkus daug kiekybinių duomenų. Vadinasi, pateikiamus kiekybinius poveikio ịvertinimus reikètų interpretuoti atsargiai, atsižvelgiant ị padarytas prielaidas ir naudotų duomenų kokybę ${ }^{26}$. Pasaulio sveikatos organizacija siūlo imunizaciją nacionaliniu lygmeniu vertinti penkiais aspektais ir atsižvelgti ị tam tikrus rodiklius ir svarbias sritis: paslaugų teikimą, infekcijų stebésenos rezultatus, logistiką (aptarnavimą), vakcinų tiekimą ir kokybę, palaikymą ir komunikaciją.

22 Čaplinskas, S.; Lileikyte, A. 2011 metų skiepijimo Lietuvoje apžvalga. Lietuvos akušerija ir ginekologija. 2013 kovas, tomas XVI, Nr. 1.

23 Užkrečiamųjų ligų ir AIDS centras. Sergamumo užkrečiamomis ligomis Lietuvoje $2012 \mathrm{~m}$. apžvalga[interaktyvus]. Vilnius, 2013 [žiūrèta 2014- 01-03]. <http://www.ulac.lt/uploads/downloads/ apzvalga_2012.pdf >.

24 Dildytè, M., supra note 15.

25 Razmuvienė D., et al. Skiepijimo apimčiu ir nepageidaujamu reakciju j ̣akcinas situacijos apžvalga Lietuvoje 2011 m. Užkrečiamųų ligų ir AIDS centras, 2012.

26 Lietuvos Respublikos finansų ministerija. ES struktūrinès paramos vertinimas: metodinès gairès. Vilnius, 2010. 


\section{Išvados ir pasiūlymai}

1. Nacionalinès imunoprofilaktikos programoje nustatytas tikslas ir jo rezultatas - „išlaikyti ne mažesnị kaip 90 proc. vaikų skiepijimo mastą visoje šalyje“ pagal rezultatyvumo kriterijų pasiektas.

2. Vertinant 2009-2012 metų skiepijimų tendencijas Lietuvoje, aiškiai stebima skiepijimo apimčių mažejimo tendencija.

3. Vertinant pastarųjų metų bendrą skiepijimo apimčių mažejjimo tendenciją, tikslinga įvertinti ir stiprinti viešają komunikaciją bei kelti medikų profesinę kvalifikaciją imunoprofilaktikos klausimais.

\section{Literatūra}

1. Country summaries of WHO/UNICEF estimated and official coverage [interaktyvus]. [žiūrèta 2014- 01-03]. <http://apps.who.int/immunization_monitoring/globalsummary/ wucoveragecountrylist.html $>$.

2. Čaplinskas, S.; Lileikytė, A. 2011 metų skiepijimo Lietuvoje apžvalga. Lietuvos akušerija ir ginekologija. 2013 kovas, tomas XVI, Nr.1.

3. Dildytè, M. Lietuvos sveikatos programos igyvendinimas - imunoprofilaktikos pokyčiu vertinimas. Magistro baigiamasis darbas. Vilnius: Mykolo Romerio universitetas, 2012.

4. Dvilevič, A. Igyvendinamos Lietuvos nacionalinès imunoprofilaktikos programos 2009-2013 m. vertinimas. Magistro baigiamasis darbas. Vilnius: Mykolo Romerio universitetas, 2013.

5. Global Immunization Visionand Strategy 2006-2015. World Health Organization. Geneva. 2005. (WHO/IVB/05.05).

6. Glatman-Freedman, A.; Nichols, K. The effects of social determinants of immunization programs. Hum Vaccin Immunotech. 2010, (28): 5731-5737.

7. Immunization Profile - Lithuania.World Health Organization [interaktyvus]. [žiūrèta 2014-01-03. <http://apps.who.int/immunization_monitoring/en/globalsummary/countryprofileresult.cfm?C=ltu>.

8. Lietuvos Respublikos Seimo 1998 m. liepos 2 d. nutarimas Nr. VIII-833 „Dèl Lietuvos sveikatos programos patvirtinimo“. Valstybės žinios. 1998, Nr. 64-1842.

9. Lietuvos Respublikos sveikatos apsaugos ministro $2008 \mathrm{~m}$. gruodžio 4 d. įsakymas Nr. V-1183 „Dèl Lietuvos Sveikatos Programos igyvendinimo tarpinio vertinimo ataskaitos patvirtinimo“. <www.sam.lt>.

10. Lietuvos Respublikos sveikatos apsaugos ministro $2009 \mathrm{~m}$. kovo $31 \mathrm{~d}$. issakymas Nr. V-242 „Dèl Nacionalinès imunoprofilaktikos 2009-2013 metų programos patvirtinimo“. Valstybès žinios. 2009, Nr. 40-1534.

11. Lietuvos Respublikos sveikatos apsaugos ministro 2006 m. rugpjūčio 8 d. ịsakymas Nr. V-682 „Dèl Nacionalinès imunoprofilaktikos 2006-2008 metų programos patvirtinimo“. Valstybès žinios. 2006, Nr. 88-3486.

12. Lietuvos Respublikos sveikatos apsaugos ministro $2007 \mathrm{~m}$. gruodžio $22 \mathrm{~d}$. ịsakymas Nr. V-1066 „Dèl Lietuvos Respublikos vaikų profilaktinių skiepijimų kalendoriaus“. Valstybés žinios. 2008, Nr. 1-27.

13. Lietuvos Respublikos Vyriausybės 2002 m. birželio 6 d. nutarimas Nr. 827 „Dèl strateginio planavimo metodikos patvirtinimo“. Valstybès žinios. 2002, Nr. 57-2312; 2010 Nr.102-5279.

14. Lietuvos Respublikos žmonių užkrečiamųjų ligų profilaktikos ir kontrolès i̇statymas 1996 m. rugsėjo 25 d. Nr. I-1553. Valstybès žinios.1996, Nr. 104-2363. 11 str. 
15. Lietuvos Respublikos finansų ministerija. ES struktūrinès paramos vertinimas: metodinès gairès. Vilnius, 2010.

16. Nacionalinès sveikatos tarybos metinis pranešimas. Lietuvos sveikatos programa: rezultatai ir išvados, 2011 [interaktyvus]. [žiūrèta 2014- 01-03 ]. <www.lrs.lt>.

17. Razmuvienė D., et al. Skiepijimo apimčiu ir nepageidaujamu reakcijų i vakcinas situacijos apžvalga Lietuvoje $2011 \mathrm{~m}$. [interaktyvus]. [žiūrèta 2014- 01-03]. <www.ulac.lt>.

18. Sveikatos sistemos reformų analizè. Ataskaita [interaktyvus]. [žiūrèta 2014- 01-03]. <http://www.sveikatosprojektai.org/node/40>.

19. Užkrečiamųjų ligų ir AIDS centras. Ataskaitos. 2013 [interaktyvus]. [žiūrèta 2014- 0103]. <www.ulac.lt>.

20. Užkrečiamųjų ligų ir AIDS centras. Sergamumo užkrečiamomis ligomis Lietuvoje 2012 m. apžvalga [interaktyvus]. Vilnius, 2013 [žiūrèta 2014- 01-03]. <http://www.ulac.lt/ uploads/downloads/apzvalga_2012.pdf >.

\title{
Lithuanian Immunization Program - Vaccination Coverage Evaluation by the Effectiveness Criteria
}

\author{
Irma Čaplinksienė \\ Mykolas Romeris University, Lithuania
}

\section{Summary}

The article aims at evaluating the implementation of the National Immunization Programme 2009-2013 by assessing the effectiveness in reaching the intermediate targets. The article looks at the trends in the vaccination coverage by diseases that are vaccinated against in accordance with Lithuanian Childhood Vaccination Schedule. Vaccinations given according to the schedule are covered by the National Health Insurance Fund in pursuance of the National Immunization Programme. The effectiveness was assessed by comparing the target indicators to the actual ones. It was found that in 2012 vaccination coverage for all infections was more than 90\%, consequently, the target of the National Immunization Programme - "to maintain the coverage among children across the country at levels no less than 90\%" - was successfully achieved by the effectiveness criteria. However, it was also noted that in recent years a visible downward trend in overall vaccination coverage has been observed, and the target to increase the scale of immunization against communicable diseases in pursuance of Lithuanian Immunization Schedule up to 97-98\% by the year 2010, which was set in the Lithuanian Health Programme, basically has remained unfulfilled. This might have been influenced by anti-vaccine movements that have been gaining momentum in the country and not evidence-based information being disseminated through the mass media.

Keywords: vaccination coverage, immunization coverage, effectiveness.

Irma Čaplinskienė, Mykolas Romeris University, Faculty of Politics and Management, Institute of Political Science, lecturer. Research interests: Health policy and Management.

Irma Čaplinskienè, Mykolo Romerio universiteto Politikos ir vadybos fakulteto Politikos mokslų instituto lektorè. Mokslinių tyrimų kryptys: sveikatos politika ir vadyba. 